\title{
NOTA PRELIMINAR
}

\author{
POR \\ JUAN DURAN LUZIO \\ Universidad Nacional \\ Heredia, Costa Rica
}

Una especie de consenso crítico, local y externo, sostiene que la literatura costarricense es un hecho cultural del siglo veinte; son muy pocos los documentos literarios que datan de la colonia y pocos los del siglo pasado. Enrique Anderson Imbert de algún modo consagró esa particularidad: «De estas tierras de América salió esta nación, Costa Rica, pero salió sin literatura. Durante casi cuatro siglos estas tierras no produjeron escritores...» La explicación de esta carencia se suele referir a las condiciones históricas del país: la escasez de oro o plata en la región no fue incentivo para un tráfico humano numeroso que pudiese portar algunas semillas del legado literario español; la mano de obra indígena poco abundante y la esporádica resistencia ante el invasor privaron a las letras de un espacio temático apropiado para las cartas de relación o la poesía épica. La Universidad, además, se fundó aquí ya mediado el siglo diecinueve.

Como se sabe, la independencia de España no fue un hecho cruento en Centroamérica, que dependía políticamente de la Capitanía General de Guatemala, parte, entonces, del Virreinato de la Nueva España. Los conflictos se originaron con posterioridad y fueron causados principalmente por la disputa en torno a la formación de un solo Estado centroamericano, frente a la noción de países independientes. Las tensiones entre liberales y conservadores, generalizadas por todo el continente, activaron en Costa Rica la polémica relativa al futuro de la patria. La imprenta no se instala hasta 1830 , y en torno a aquellos dilemas se publican incipientes manifestaciones literarias; algo después, el Modernismo aportará las enseñanzas de una literatura distinta que, sin embargo, no encuentra un camino fácil porque el realismo costumbrista, difundido también aquí por el maestro 
Larra y algunos de sus discípulos americanos, comenzaba a generar una tendencia nacionalista llamada a larga vida en las letras costarricenses.

La antítesis campo versus ciudad, con alcances políticos distintos y menos evidentes de los que tenía en Sarmiento, refíeja bien, sin embargo, el conflicto sociológico de un país de fuerte raigambre rural; no es extraño, pues, que se convierta en tema literario de amplia vigencia. El predominio de la temática agraria se desarrolla con diferentes matices hasta bien entrado el siglo presente, y asume los conflictos políticos y sociales más serios vividos por el país. Es primero una suerte de naturalismo al modo zolaciano, y más tarde un discurso denunciatorio bastante directo; la fuerza doctrinaria que paralelamente alienta este proceso de madurez está constituida por el rico espectro de inquietudes americanistas prestigiado desde los escritos de José Martí y José Enrique Rodó. Con estos antecedentes, una narrativa anti-imperialista sobresale en Costa Rica, como en el resto de Centroamérica, desde los años cuarenta, situando las dolorosas geografías de las bananeras, de las grandes plantaciones. En las décadas siguientes se asiste a una mesurada renovación temática y formal de la prosa; parece expresarse así, igualmente, el cambio hacia una sociedad más compleja y diversificada.

La lírica, que se inicia también en estrecha cercanía con los temas campesinos, salvo algunos intentos cosmopolitas de los modernistas, ha seguido un curso similar en búsqueda de una expresión más universal, capaz, al mismo tiempo, de situar con claridad y hondura al hombre del país y su condición en el mundo.

Desde el umbral que proporciona 1900, y como se confirma en este número, se afianzan las bases de un desarrollo cultural que, a partir de entonces, se insertan cabalmente en el proceso dinámico de la literatura hispanoamericana. En este sentido, las expresiones literarias de Costa Rica han sido, por lo general, tardías con respecto a las del resto del continente, pero no son excepciones entre los grandes movimientos, tendencias o influjos que se manifiestan desde México hasta la Argentina; acaso este carácter epigonal sea su rasgo más típico, aunque en el presente esta particularidad tiende a disminuir por los crecientes contactos con los creadores y las obras de vanguardia.

Los estudios que siguen a continuación mostrarán, desde diversas perspectivas, el transcurso del proceso literario en la Costa Rica moderna; al respecto conviene señalar que las visiones interpretativas ofrecidas aquí varían ampliamente: desde el ensayo tradicional hasta la monografía estructuralista, dando cuenta así, en cierta manera, de las tendencias de la crítica literaria en el país. En general, esta actividad está situada en los linderos del trabajo universitario; la gran mayoría de nuestros colabora- 
dores locales se desempeña en el área docente y, en casi todos los casos, junto con la literatura nacional, enseñan la del resto del continente hispanoamericano. Resulta justo reconocer en esa variedad de posiciones analíticas la madurez que las disciplinas, tanto críticas como pedagógicas, han alcanzado en este medio.

Es probable que las lagunas sean más notorias de lo deseado; pero la intención de este número es ofrecer una muestra significativa, aunque no exhaustiva, de las letras de Costa Rica. Y en este sentido se encuentran bien representadas las expresiones más salientes de su literatura. Como en la mayoría de nuestros países, se verá en el caso de Costa Rica un predominio de la narrativa, particularmente de la novela, por sobre la lírica y, sin duda, por sobre el ensayo y la dramaturgia. Acaso éste, más que un problema de producción, sea uno de lectura y crítica; y aunque no podemos sustentar cuantitativamente la primacía de un género sobre los otros, sí es posible ilustrar las preferencias de la crítica por la novela, como se verá en adelante. Es claro que no se trata de establecer relaciones entre cantidad y calidad: éste es nada más un hecho que convenía señalar en beneficio de cierta uniformidad del quehacer literario nacional con el del resto del continente.

Las políticas culturales del país han permitido una libre circulación de las obras literarias, propias y extranjeras, y los escritores no han sufrido los apremios denunciados por tantas partes de Hispanoamérica. La literatura se desenvuelve, pues, en un espacio de libertad. Costa Rica es un país pequeño: el censo de hace un par de años indicó una población de dos millones y medio de habitantes, en sus cincuenta y dos mil kilómetros cuadrados de extensión. Acaso esta situación impone diferencias a la producción literaria costarricense ante naciones como Argentina, Colombia, Chile, México, Perú; sin embargo, serán evidentes las coincidencias formales y temáticas, las metas de esta escritura, sus logros y carencias, lo que da vida a estas creaciones hermanas de aquéllas, descendientes de iguales tradiciones. Literatura inserta, al fin y al cabo, en las mismas corrientes profundas que había señalado Pedro Henríquez Ureña.

Terminan estas líneas agradeciéndole al profesor Alfredo Roggiano su vocación americanista y su amable concesión de un espacio en la Revista Iberoamericana para poner ante un lector distante este bosquejo de una cultura que también lucha por destruir la dura cáscara de la soledad. 
